\title{
A new species of Astyanax (Characiformes: Characidae) from the rio de Contas basin, Bahia, Brazil
}

\author{
Angela Maria Zanata ${ }^{1}$, Rafael Burger ${ }^{1}$, George $_{\text {Vita }}{ }^{2}$ and Priscila Camelier ${ }^{1}$
}

A new species of Astyanax from tributaries of the rio de Contas, Bahia, Brazil, is described. The new species differs from congeners by having three horizontal series of scales from lateral line to pelvic-fin origin and the distal margin of third infraorbital distinctly separated from vertical and horizontal limbs of preopercle, leaving a broad area not covered by superficial bones. The new species further differs from most congeners by the presence of bony hooks on all fins of mature males. Particularly from congeners occurring in rivers of the Northeastern Mata Atlântica freshwater ecoregion, it further differs by having the highest body depth just anterior to the dorsal-fin origin, 34-37 pored lateral line scales, a vertically elongated conspicuous dark humeral blotch reaching below the lateral line and a conspicuous dark wide midlateral stripe extending from the clear area on the rear of the humeral blotch to the end of middle caudal-fin rays and forming an inconspicuous blotch on caudal peduncle.

Keywords: Endemism, Northeastern Mata Atlântica freshwater ecoregion, Sexual dimorphism, Taxonomy.

Uma espécie nova de Astyanax de tributários do rio de Contas, Bahia, Brasil, é descrita. A espécie nova difere das congêneres por ter três séries horizontais de escamas entre a linha lateral e a origem da nadadeira pélvica e margem distal do terceiro infraorbital distintamente separada dos ramos vertical e horizontal do pré-opérculo, deixando uma ampla área sem ossos superficiais. A espécie nova difere, ainda, da maioria das congêneres pela presença de ganchos ósseos em todas as nadadeiras de machos maduros. Particularmente das congêneres que ocorrem nas drenagens da Ecorregião Mata Atlântica Nordeste, difere ainda por ter a maior altura do corpo imediatamente anterior à origem da nadadeira dorsal, 34-37 escamas perfuradas na linha lateral, presença de uma mancha umeral conspícua, verticalmente alongada, ultrapassando ventralmente a linha lateral e uma faixa escura mediana lateral larga, estendendo-se da área clara após a mancha umeral até o fim dos raios medianos caudais e formando uma mancha inconspícua no pedúnculo caudal.

Palavras-chave: Dimorfismo sexual, Ecorregião Mata Atlântica Nordeste, Endemismo, Taxonomia.

\section{Introduction}

Astyanax Baird \& Girard is one of the most species-rich genera within Characidae, with 176 valid species (Fricke et al., 2019). Furthermore, possibly it is among the genera with higher number of species being described lately, with approximately 80 new species in the last 20 years. Particularly to drainages inserted in the Northeastern Mata Atlântica freshwater ecoregion (sensu Abell et al., 2008; NMAF), 11 species were described in that period (e.g., A. brucutu Zanata, Lima, Di Dario \& Gerhard, A. epiagos Zanata \& Camelier, A. hamatilis Camelier \& Zanata, A. lorien Zanata, Burger \& Camelier, A. pelecus Bertaco \& Lucena, A. sincora Burger, Carvalho \& Zanata). All of them are apparently endemic to their respective river basin and none of them or other known species of Astyanax was described from the rio de Contas basin. Taxonomic aspects of the ichthyofauna of the rio de Contas are known basically by description of new species of different taxa [e.g., Cyphocharax pinnilepis Vari, Zanata \& Camelier, Hasemania piatan Zanata \& Serra, Hyphessobrycon brumado Zanata \& Camelier, Ituglanis agreste Lima, Neves \& Campos-Paiva, Megaleporinus brinco (Birindelli, Britski \& Garavello), Nematocharax varii Barreto, Silva, Batalha-Filho, Affonso \& Zanata]. Some of these studies represent the few citations regarding species of Astyanax to the rio de Contas basin, usually solely as syntopic fauna to their new species. Other relevant studies including species of Astyanax from the rio de Contas have citogenetic or molecular approaches (e.g., Affonso et al., 2007; Medrado et al., 2008, 2015; Pamponet et al., 2008), or are represented by not published thesis (e.g., Silva, 2015). Recent ichthyological surveys in the rio de Contas basin yielded a new species of Astyanax apparently endemic to this basin that is described herein.

\footnotetext{
${ }^{1}$ Instituto de Biologia, Universidade Federal da Bahia, Rua Barão de Jeremoabo, 147, Ondina, 40170-115 Salvador, BA, Brazil. (AMZ) zanata.angela@gmail.com (corresponding author), (ohttps://orcid.org/0000-0001-6500-8562; (RB) rafaelburger1984@gmail.com, (Dhttps://orcid.org/0000-0002-9165-4792; (PC) pricamelier@gmail.com, Dhttps://orcid.org/0000-0002-1228-0076

${ }^{2}$ Museu de Zoologia da Universidade de São Paulo, Caixa Postal 42494, 04218-970 São Paulo, SP, Brazil. georgevita@usp.br, (Dhttps://orcid.org/0000-0003-2527-1950
} 


\section{Material and Methods}

Counts and measurements were taken according to Fink, Weitzman (1974) and Menezes, Weitzman (1990). In Tab. 1, standard length (SL) is expressed in $\mathrm{mm}$ and all other measurements are expressed as a percentage of SL, except subunits of the head that are expressed as percentages of head length (HL). Meristic data are provided in the description, an asterisk indicates counts of the holotype and the frequency of each count is given in parentheses. The number of horizontal scale rows between dorsal-fin origin and the lateral line does not include a scale of predorsal series situated just anterior to first dorsal-fin ray or the short series of small scales just below dorsal-fin base. Counts of vertebrae, supraneurals, procurrent caudal-fin rays, branchiostegal rays, and gill rakers were taken only from cleared and stained specimens (c\&s), prepared according to Taylor, Van Dyke (1985). Precaudal vertebrae include the Weberian apparatus and the vertebrae associated with ribs or haemal arches without haemal spines. Caudal vertebrae are vertebrae associated with haemal spines. The fused first preural and first ural centrum of the caudal region are counted as a single element. The pattern of circuli and radii was examined on scales sampled from the region between the lateral line and the dorsal-fin origin. The sex of specimens was confirmed by dissection. Institutional abbreviations follow Fricke, Eschmeyer (2019). Comparisons with species not cited in the 'Comparative material examined' were based on the literature information (e.g., Eigenmann, 1911, 1921, 1927; Azpelicueta, Garcia, 2000; Melo, 2000; Bertaco, Malabarba, 2001; Azpelicueta et al., 2002a, b; Almirón et al., 2002; Triques et al., 2003; Haluch, Abilhoa, 2005; Bertaco, Lucena, 2006; Abilhoa, Duboc, 2007; Alcaraz et al., 2009; Azpelicueta, Loureiro, 2009; Bertaco, Lucena, 2010; Bertaco et al., 2010; Garavello, Sampaio, 2010; Tagliacollo et al., 2011; Lucena et al., 2013, 2017; Oliveira et al., 2013, 2017; Ingenito, Duboc, 2014; Zanata et al., 2017).

\section{Astyanax varii, new species}

urn:1sid:zoobank.org:act:2C8775FD-4CA7-4D0B-8C9DC338A88DFEC2

\section{Figs. 1-3; Tab. 1}

Astyanax sp. 6.-Camelier, Zanata (2014):686, tab. 1 [listed; species from the Northeastern Mata Atlântica freshwater ecoregion].

Astyanax sp.-Barreto et al. (2018): 1158 [citation; co-occurence with Nematocharax varii].

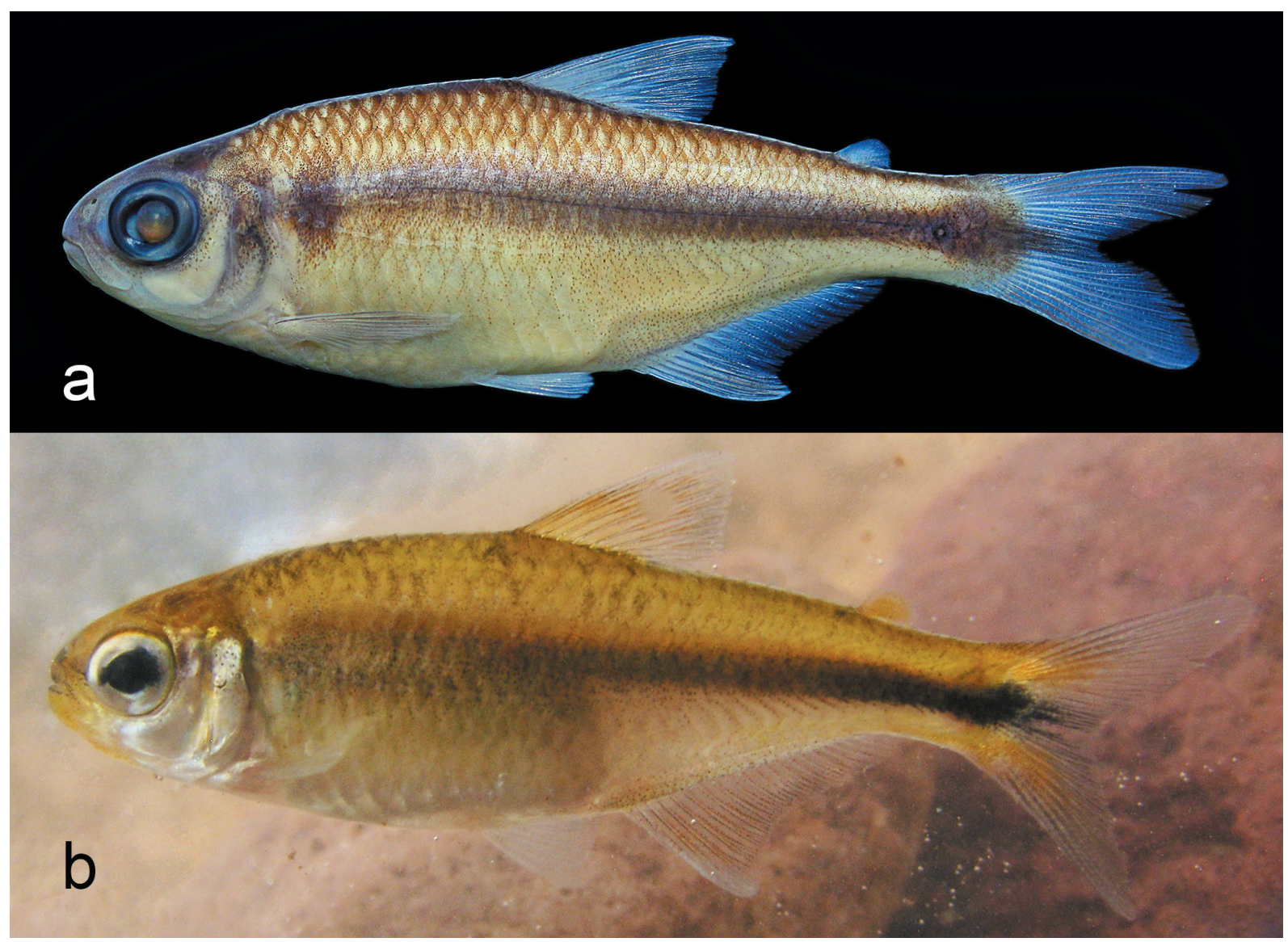

Fig. 1. Astyanax varii, Brazil, Bahia State: (a) MZUSP 121062, holotype, $41.4 \mathrm{~mm}$ SL, Ubaitaba, lower rio de Contas basin, rio Coricó; (b) live paratype, not catalogued. 
Holotype. MZUSP 121062, 41.4 mm SL, Brazil, Bahia, Ubaitaba, rio Coricó in Fazenda Progresso, near the road BR330, lower rio de Contas basin, 14¹4'50'S 39²2'39'W, 65 m above sea level (a.s.1.), 13 Feb 2008, A. M. Zanata, R. Burger, P. Camelier \& A. B. A. Góes.

Paratypes. All specimens from Brazil, Bahia, rio de Contas basin. MCP 54205, 10, 31.9-40.3 mm SL; UFBA 8405, 16, 22.2-41.4 mm SL, 2 c\&s 35.1-36.7 mm SL, rio Água Suja on road BA-148, border between Abaíra and Jussiape, upper

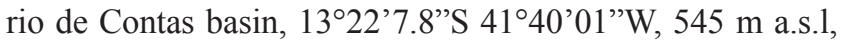
18 Jun 2017, A. M. Zanata, R. Burger \& G. V. Oliveira. MZUSP 112058, 6, 21.4-34.0 mm SL, rio Gongogi on the border between Itajibá and Ibicuí municipalities, lower rio de Contas basin, 14²1'16.5'S 3946'23.9'W, $164 \mathrm{~m}$ a.s.1, 13 Aug 2012, J. L. O. Birindelli, F. C. P. Dagosta \& M. V. Loeb. MZUSP 125529, 10, 30.3-44.3 mm SL; UFBA 4515, 14, 26.2-41.3 mm SL, collected with the holotype. MZUSP 125530, 24, 34.1-40.3 mm SL; NUP 21946, 10, 26.0-36.8 mm SL; UFBA 8380, 49, 22.8-41.0 mm SL, 2 c\&s 34.5-41.0 $\mathrm{mm}$ SL, Jussiape, Caraguataí, rio Água Suja at Balneário Rio da Barra, upper rio de Contas basin, 13²4'14.5"S 41'38'7.8'W, 529 m a.s.1., 18 Jun 2017, A. M. Zanata, R. Burger \& G. V. Oliveira. UFBA 8450, 4, 24.8-39.5 mm SL, rio Água Suja, on road BA-148, between Abaíra and Jussiape, upper rio de Contas basin, 13²4'35.4'S 41³7'60”W, 531 $\mathrm{m}$ a.s.1., 5 Mar 2017, A. M. Zanata \& R. Burger. UFBA 7046, 3, 28.8-33.2 mm SL, Dário Meira, rio Gongogi under bridge in Dário Meira, lower rio de Contas basin, 14²6'12'S 3954'13.4'W, $180 \mathrm{~m}$ a.s.1., 12 Dec 2011, A. M. Zanata, P. Camelier, J. O. Birindelli, R. Burger \& B. Sardeiro.

Diagnosis. Astyanax varii can be distinguished from most congeners, except $A$. brachypterygium Bertaco \& Malabarba, A. brucutu, A. cremnobates Bertaco \& Malabarba, A. epiagos, A. eremus Ingenito \& Duboc, $A$. gymnogenys Eigenmann, $A$. rupestris Zanata, Burger \& Camelier, A. taeniatus (Jenyns), A. totae Haluch \& Abilhoa, and A. varzeae Abilhoa \& Duboc, by having the distal margin of third infraorbital distinctly separated from vertical and horizontal limbs of preopercle (Fig. 2), leaving a broad area without superficial bones (vs. margins of the third infraorbital close to the limbs of preopercle, with narrow or no space between the two bones). The new species differs from the aforementioned species by having three horizontal series of scales from the lateral line to the pelvic-fin origin ( $v s$. four or more series of scales) and by having small bony hooks on all fins of mature males (vs. bony hooks absent or not present on all fins of mature males). Astyanax varii also differs from the species listed above by having highest body depth approximately at vertical through dorsal-fin origin ( $v s$. body deepest on a vertical through middle or posterior portion of pectoral fin in A. brachypterygium, A. cremnobates, A. epiagos, $A$. eremus, A. gymnogenys, $A$. rupestris, $A$. totae, and $A$. varzeae), five horizontal series of scales from the dorsal-fin origin to the lateral line ( $v s$. six or more in A. brachypterygium, A. brucutu, A. cremnobates, $A$. eremus, $A$. rupestris, $A$. totae, $A$. taeniatus, and $A$. varzeae), 14 horizontal scale rows around caudal peduncle (vs. 15 or more in $A$. brachypterygium, A. eremus, A. gymnogenys, and A. totae), and 34-37 pored lateral line scales (vs. 38 or more in A. eremus, A. gymnogenys, and A. taeniatus).

Description. Morphometric data of the holotype and paratypes are given in Tab. 1. Body compressed and elongate; highest body depth approximately at vertical through dorsalfin origin. Dorsal profile of head convex from upper lip to vertical through anterior nostrils; straight to slightly convex from latter point to tip of supraoccipital spine. Dorsal profile of body nearly straight to slightly convex from tip of supraoccipital spine to dorsal-fin origin; straight and posteroventrally slanted from dorsal-fin origin to adipose fin and slightly concave or nearly straight along caudal peduncle. Ventral profile of head usually straight to slightly convex from anterior tip of dentary to isthmus. Ventral body profile slightly convex from isthmus to anal-fin origin; straight and posterodorsally slanted along anal-fin base and nearly straight to slightly concave along caudal peduncle.

Head somewhat pointed to rounded anteriorly in lateral profile. Mouth terminal; upper jaw similar in length anteriorly or slightly longer than lower jaw. Posterior terminus of maxilla extending beyond vertical through anterior margin of orbit. Infraorbital series moderately developed; ventral margin of third infraorbital falling distinctly short from horizontal limb of preopercle and leaving a relatively broad area without superficial bones (Fig. 2). Number of infraorbitals variable, with $4(1)$ or $6(2)$ ossifications. One specimen with four elements on one side of head (UFBA $8380,41.0 \mathrm{~mm} \mathrm{SL}$ ) apparently presenting infraorbitals 1 and 2 as independent elements, $3+4+5$ fused resulting in one element, and infraorbital 6 independent. Supraorbital absent.

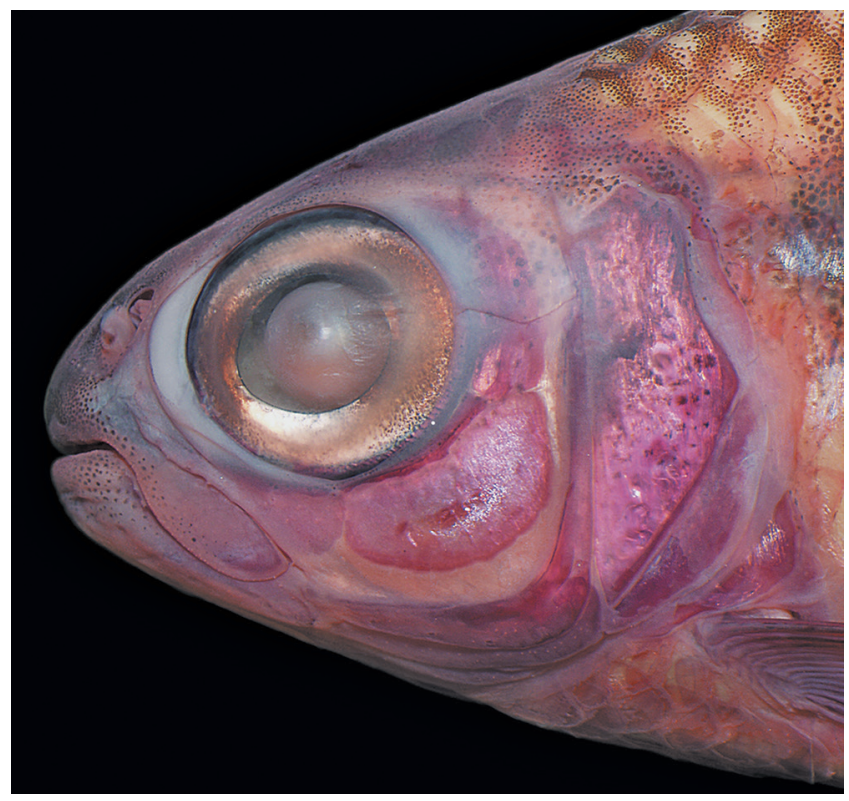

Fig. 2. Head of Astyanax varii, UFBA 8380, paratype, 40.8 $\mathrm{mm}$ SL, $9.3 \mathrm{~mm}$ HL, alizarin stained, lateral view, left side. 
Tab. 1. Morphometric data for Astyanax varii, new species; $\mathrm{n}=30$, range includes holotype. $\mathrm{SD}=$ standard deviation.

\begin{tabular}{|c|c|c|c|c|}
\hline & Holotype & Range & Mean & $\mathrm{SD}$ \\
\hline Standard length $(\mathrm{mm})$ & 41.4 & $29.1-44.3$ & 37.6 & - \\
\hline \multicolumn{5}{|c|}{ Percentages of standard length } \\
\hline Depth at dorsal-fin origin & 31.4 & $28.8-33.6$ & 31.0 & 1.4 \\
\hline Snout to dorsal fin origin & 51.0 & $48.6-53.0$ & 51.0 & 1.0 \\
\hline Snout to pectoral-fin origin & 24.4 & $23.6-26.5$ & 24.9 & 0.8 \\
\hline Snout to pelvic-fin origin & 45.7 & $45.3-48.9$ & 47.1 & 1.1 \\
\hline Snout to anal-fin origin & 61.8 & $61.2-65.3$ & 63.5 & 1.2 \\
\hline Caudal peduncle depth & 10.6 & $10.6-12.1$ & 11.4 & 0.4 \\
\hline Caudal peduncle length & 15.9 & $13.7-16.9$ & 15.0 & 0.7 \\
\hline Pectoral-fin length & 20.5 & $19.9-22.6$ & 21.2 & 0.7 \\
\hline Pelvic-fin length & 13.0 & $12.9-15.1$ & 13.9 & 0.6 \\
\hline Dorsal-fin base length & 11.6 & $11.3-14.4$ & 13.0 & 0.8 \\
\hline Dorsal-fin height & 24.4 & $23.1-26.6$ & 25.2 & 1.0 \\
\hline Anal-fin base length & 23.4 & $23.4-27.3$ & 25.2 & 1.0 \\
\hline Anal-fin lobe length & 17.6 & $15.8-20.3$ & 18.1 & 0.8 \\
\hline Eye to dorsal-fin origin & 36.2 & $35.1-37.6$ & 36.3 & 0.6 \\
\hline Dorsal-fin origin to caudal-fin base & 52.7 & $50.0-54.3$ & 52.5 & 1.1 \\
\hline Head length & 24.9 & $23.4-26.6$ & 24.9 & 0.9 \\
\hline \multicolumn{5}{|c|}{ Percentages of head length } \\
\hline Horizontal eye diameter & 38.8 & $34.7-40.0$ & 37.8 & 1.4 \\
\hline Snout length & 23.3 & $19.8-23.9$ & 22.3 & 1.0 \\
\hline Least interorbital width & 29.1 & $28.2-32.1$ & 30.6 & 1.0 \\
\hline Upper jaw length & 40.8 & $40.2-43.9$ & 42.3 & 1.2 \\
\hline
\end{tabular}

Premaxillary teeth in two rows (Fig. 3). Outer row with $2(1), 3^{*}(24)$, or $4(5)$ teeth bearing 3 or 5 cusps. Inner row with $5^{*}(30)$ teeth usually bearing 7 cusps, rarely 5 ; second tooth the largest, with 7 cusps; last tooth with 5 or 7 cusps; symphyseal tooth of inner series asymmetrical, with 1 or 2 cusps on anteromedial side, one larger central cusp and three smaller on lateral side. Maxilla with 2(7), $3^{*}(17)$, or $4(6)$ teeth bearing 5 to 7 cusps. Dentary with $8(8), 9(7), 10 *(15)$, or $11(5)$ teeth decreasing gradually in size and number of cusps posteriorly; symphyseal tooth symmetrical with 7 cusps, followed by teeth with 5 or 6 cusps and posteriormost teeth with 3 cusps.

Scales cycloid; circuli conspicuous anteriorly but absent on exposed area of scales; few parallel radii extending to posterior margin of scale. Lateral line slightly decurved ventrally, with $34(3), 35(7), 36 *(17)$, or $37(2)$ perforated scales, continuous from supracleithrum to caudal-fin base. Longitudinal scale rows between dorsal-fin origin and lateral line $5^{*}(30)$. Longitudinal scale rows between lateral line and pelvic-fin insertion $3 *(30)$. Scales along middorsal line between tip of supraoccipital process and origin of dorsal fin 9(3), 10(8), 11*(15), or irregular (4). Horizontal scale rows around caudal peduncle $14 *(29)$. Base of anteriormost anal-fin rays with single scale row composed of 4 or 5 scales. Axillary scale absent. Caudal fin not scaled.

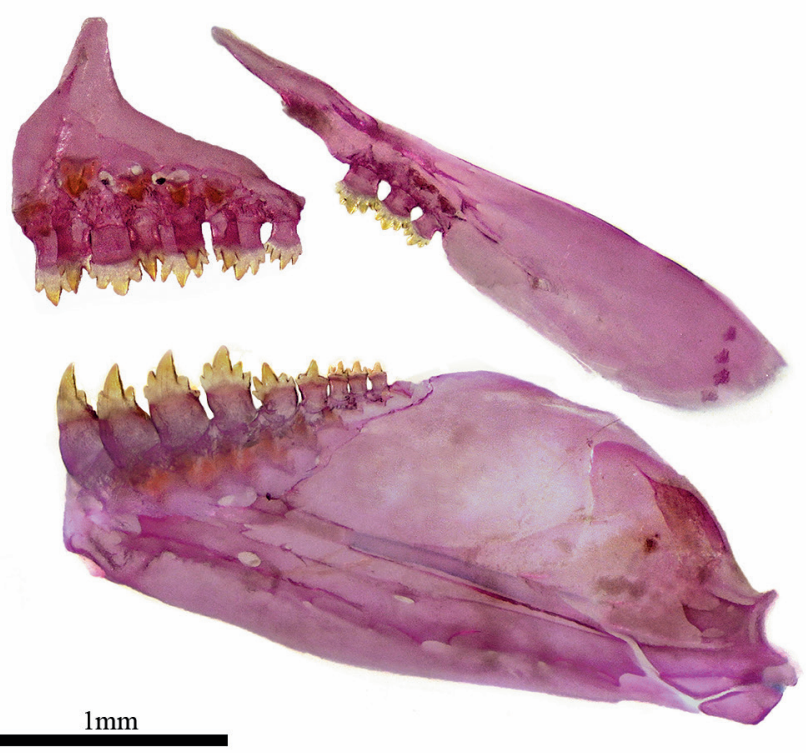

Fig. 3. Upper and lower jaws of Astyanax varii, UFBA 8405, paratype, $35.1 \mathrm{~mm} \mathrm{SL}$, lateral view, left side.

Dorsal-fin rays ii, $9 *(30)$. Distal margin of dorsal fin straight or slightly rounded. Dorsal-fin origin located approximately at middle of standard length and posterior to vertical through pelvic-fin origin. Base of last dorsal-fin ray aligned with analfin origin. First dorsal-fin pterygiophore inserting behind neural spine of $9^{\text {th }}(3)$ or $10^{\text {th }}(1)$ vertebra. Adipose fin present. Anal-fin rays iii(23), 17(3), 18*(7), 19(15), or 20(5). Distal margin of anal fin concave. First anal-fin pterygiophore inserting behind haemal spine of $16^{\text {th }}(2)$ or $17^{\text {th }}(2)$ vertebra. Pectoral-fin rays i(30), 10(1), $11 *(15)$, or 12(13). Tip of pectoral fin not reaching vertical through pelvic-fin insertion. Pelvic-fin rays i, $7 *(30)$; tip of pelvic fin not reaching first anal-fin insertion. Caudal fin forked, lobes pointed, similar in size. Principal caudal-fin rays 9+9(1), 9+10(2), or 9+11(1). Nine(1) or 11(3) dorsal procurrent caudal-fin rays and 7(1) or 10(3) ventral procurrent caudal-fin rays.

Total vertebrae 35(3) or 36(1). Precaudal vertebrae 15(3) or 16(1); caudal vertebrae 19(1) or 20(3). Supraneurals $4(2)$ or 5(2). Branchiostegal rays 4(2). First gill arch with 5(4) gill rakers on epibranchial, 8(4) on hypobranchial and ceratobranchial, and 1(4) on cartilage between ceratobranchial and epibranchial.

Color in alcohol. Overall ground color pale yellow or light brown (Fig. 1a). Guanine restricted to infraorbitals, preopercle, and opercle. Dorsal part of head moderately dark anteriorly and usually darker on posterior half; presence of two large black rounded blotch on posterior part of head in some specimens. Small melanophores sparsely distributed throughout maxilla. Infraorbitals poorly pigmented, with few melanophores close to orbit; infraorbitals four to six more pigmented, with large melanophores sparsely distributed. Opercle with sparse melanophores, usually more concentrated on its dorsal half; ventral third usually 
without dark pigmentation. Concentration of melanophores on opercle usually resembling a vertically elongated blotch, somewhat similar to the humeral blotch. Ventral portion of head pale or with a few diminute scattered melanophores on anteriormost portion. Middorsal line of body distinctly darkened. Humeral region with a conspicuous vertically elongated humeral blotch, formed by underlying and superficial melanophores; blotch over two or three scales on horizontal series immediately above lateral line, tapering ventrally and occupying one scale below lateral line. Humeral blotch bordered anteriorly and posteriorly by clearer areas. Dark broad midlateral stripe extending from the rear of clear area posterior to humeral blotch to caudal peduncle. A dark rounded blotch, with inconspicuous borders, present on caudal peduncle in most specimens; blotch when present, partially merged with the stripe. Two or three dorsalmost longitudinal scale series of flank usually with dark small chromatophores concentrated along their posterior margins, resulting in reticulate pattern; center of scales clearer, with few sparse larger melanophores; some specimens darker overall and reticulate pattern substituted by a more homogeneous dark pigmentation on scales. In some specimens with more defined reticulate pattern, the dark margins of scales are narrower along lateral line and one to three horizontal series of scales below it. Remaining scales along flank with sparse melanophores; dark lines usually present along myosepts above anal-fin base. Abdominal region clear. All fins darkened in some degree, with sparse melanophores concentrated on margins of rays; dorsal, anal, and caudal fins somewhat darker than pectoral and pelvic fins. Adipose fin with scattered small melanophores.

Color in life. Color pattern similar to the described in alcohol (Fig. 1b). Overall ground color yellow. Iris, infraorbitals, and opercle silvery. Humeral blotch faint or not discernible. Dark midlateral stripe more conspicuous on posterior half of body, extending to middle caudalfin rays. Unpaired fins yellowish at least on its proximal half. Pectoral and pelvic fins hyaline or poorly pigmented. Adipose fin yellowish.

Sexual dimorphism. Mature males of Astyanax varii have variable presence of hooks on fins and the examined mature females have no bony hooks on any of the fins. Some mature males possess tiny bony hooks on all fins (e.g., UFBA 4515, 29.1-34.3 mm SL), but most mature males have hooks restricted to the pectoral, pelvic, and anal fins. Anal fin of mature males with one to six hooks distributed up to the tenth first branched ray; hooks more numerous and larger on the anterior branched rays and always distally located on the posterior branch of rays. When present in the dorsal fin, up to six small hooks distributed on the first eight branched rays; hooks always distally located on the posterior branch of ray. Pectoral fins of mature males with up to six tiny hooks on the distal portion of up to the seventh branched ray. Pelvic fins with two or three small hooks on the distal portion of third to the sixth branched rays. When present in the caudal fin, very small hooks restricted to the four centralmost caudalfin rays. No other dimorphic morphological character was observed externally in the specimens examined, except by the body size. Females apparently reach larger body sizes than males (largest female observed $53.3 \mathrm{~mm}$ SL vs. largest male $37.9 \mathrm{~mm} \mathrm{SL}$ ). Males are completely mature around $29.0 \mathrm{~mm} \mathrm{SL}$ and females at the same size are completely immature. The smallest mature female examined had 35.0 $\mathrm{mm}$ SL.

Geographical distribution. Astyanax varii is known from tributaries of rio de Contas basin, Bahia State, Brazil (Fig. 4).

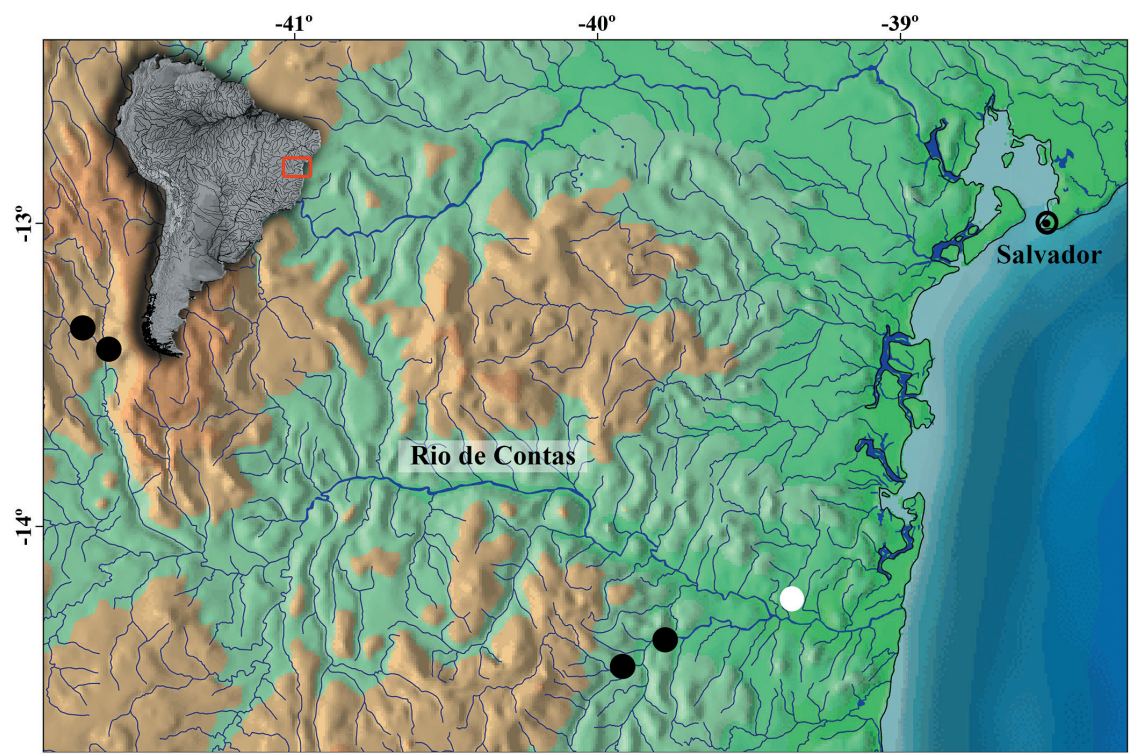

Fig. 4. Collection localities of Astyanax varii, rio de Contas basin, Bahia, Brazil. White dot = type locality; black dots = additional localities. Some circles indicate more than one sampling site. 
Ecological notes. Astyanax varii was collected in three localities of the upper and three of the lower rio de Contas basin, in altitudes ranging from 65 to $545 \mathrm{~m}$ a.s.l. (Figs. $5 \mathrm{a}-\mathrm{b})$. The stretches sampled in tributaries of the lower portion of the basin are 5-25 m wide, up to $1.8 \mathrm{~m}$ deep, with rocky, muddy, or sandy substrate and bordered by aquatic vegetation and trees. In that localities, $A$. varii was collected syntopically with 13 species: Apareiodon itapicuruensis Eigenmann \& Henn, Astyanax sp., Cetopsorhamdia iheringi Schubart \& Gomes, Cyphocharax pinnilepis, Geophagus brasiliensis (Quoy \& Gaimard), Hemigrammus marginatus Ellis, Hypostomus sp., Leporinus bahiensis Steindachner, Nematocharax venustus Weitzman, Menezes \& Britski, Poecilia reticulata Peters, Serrapinnus piaba (Lütken), Serrapinnus sp., and Serrasalmus brandti Lütken. In the upper rio de Contas, the species was sampled in three nearby locations in the rio Água Suja. One of them is the Balneário Rio da Barra (Fig. 5b), an artificial reservoir approximately $100 \mathrm{~m}$ long, $30 \mathrm{~m}$ wide, and $1.1 \mathrm{~m}$ deep on average, which is used mostly as a bathing place. The other sampling points in the rio Água Suja are up to $12 \mathrm{~m}$ wide and up to $1 \mathrm{~m}$ deep, with rocky and sandy-bottomed habitats, moderate water current, and with riparian vegetation mainly composed by grass and sparse trees. In those localities, $A$. varii was collected syntopically with 16 species: Acestrorhynchus lacustris (Lütken), Apareiodon itapicuruensis, Astyanax aff. lacustris (Lütken), Astyanax aff. fasciatus (Cuvier), Characidium sp., Cyphocharax gilbert (Quoy \& Gaimard), Coptodon sp., Geophagus brasiliensis, Hemigrammus marginatus, Hypostomus sp., Leporinus sp., Megaleporinus brinco, Nematocharax varii, Parotocinclus sp., Poecilia reticulata, and Serrrasalmus brandti.

The analysis of stomach contents of two specimens of $A$. varii revealed the presence of allochthonous and autochthonous items, composed predominantly by filamentous algae and fragments of vascular plants and seeds, organic debris, insect aquatic larvae (Diptera: Chironomidae and Simuliidae) and fragments of unidentified insects.

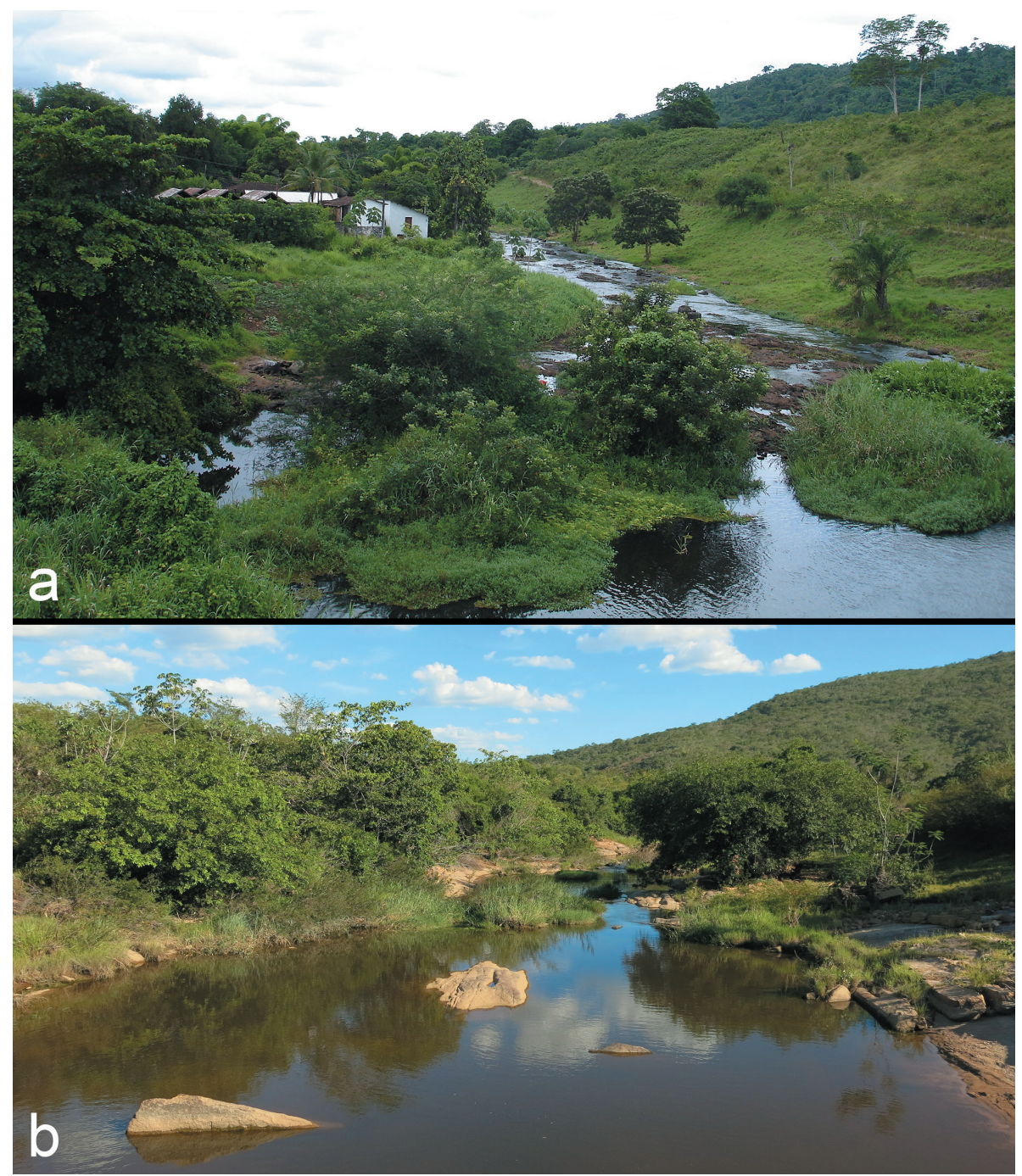

Fig. 5. Collecting sites of Astyanax varii: (a) type locality, Brazil, Bahia State, Ubaitaba, Fazenda Progresso, rio Coricó, lower rio de Contas basin; (b) Brazil, Bahia State, Jussiape, Caraguataí, rio Água Suja at Balneário Rio da Barra, upper rio de Contas basin. 
Etymology. The specific name varii is in honor to the ichthyologist Richard P. Vari for his friendship, mentoring, and outstanding contribution to the systematic of South American freshwater fishes.

Conservation status. Astyanax varii had been collected in six localities in the upper and lower rio de Contas basin. The main locality sampled in the upper rio de Contas, the Balneário Rio da Barra, is an artificial reservoir continually exploited for tourism as a bathing place (Barreto et al., 2018). Permanent anthropic perturbation such as loss of riparian vegetation and dams occurs in the main channel and some tributaries of rio de Contas (Cetra et al., 2010; SarmentoSoares et al., 2016). Despite some records of threats for the region, such as deforestation, water pollution, and erosion, there are no data about the direct effects of these threats to the populations of $A$. varii so far. Therefore, with the currently available data, and according to the International Union for Conservation of Nature (IUCN) categories and criteria (IUCN Standards and Petitions Subcommittee, 2017), A. varii should be classified as Least Concern (LC).

\section{Discussion}

A total of 79 species of Astyanax was described in the last 20 years (Fricke et al., 2019), being one of the fish genera with higher expansion on its richness knowledge. Advances in alpha taxonomy of the ichthyofauna of the Brazilian coastal drainages contributed with 21 of those descriptions, being 11 from the Northeastern Mata Atlântica freshwater ecoregion (e.g., Rangel-Pereira, 2012; Birindelli et al., 2013; Lima et al., 2013; Mattos, Costa, 2018; Barreto et al., 2018; Burger et al., 2019); seven from rivers draining the Laguna dos Patos freshwater ecoregion (e.g., Lucena et al., 2013; Bertaco, Vigo, 2015), one species from the Tramandaí-Mampituba freshwater ecoregion (Bertaco, 2014), one species from the Ribeira de Iguape freshwater ecoregion (Silva et al., 2019), and one from the Southeastern Mata Atlântica freshwater ecoregion (Oliveira et al., 2013). Particularly to the NMAF, nine of the 11 species mentioned are from river basins inserted in the Bahia State, highlighting the rio Paraguaçu basin, with six described species, all of them apparently endemic to this basin (A. brucutu, A. epiagos, A. hamatilis, A. lorien, A. rupestris, and A. sincora). Conversely, Astyanax is poorly documented to the rio de Contas basin in the taxonomic literature, being usually not identified confidently at specific level [e.g., Astyanax gr. bimaculatus (Linnaeus) in Cetra et al., 2010; A. aff. lacustris (Lütken) in Zanata, Camelier, 2010; A. gr. fasciatus and A. gr. lacustris in Barreto et al., 2018] or identified as Astyanax sp. (e.g., Camelier, Zanata, 2014; Sarmento-Soares et al., 2016). Similarly, species of Astyanax are alternately confidently identified at specific level or not in cytogenetics or molecular studies (e.g., A. fasciatus in Medrado et al., 2008; A. aff. fasciatus in Medrado et al., 2015; A. aff. bimaculatus in Pamponet et al., 2008; A. bimaculatus in Lima et al., 2013). Such taxonomic difficulties corroborate the poor geographical and taxonomic species delimitation of the species complexes in which the species cited above are included. Also, the cited shortcomings confirm the need of comparative taxonomic studies, including populations of Astyanax from the rio de Contas basin, to check for the presence of A. fasciatus, $A$. bimaculatus, or A. lacustris in this basin.

Astyanax varii is the first species of the genus described from the rio de Contas and the species does not fit in any of the species groups, traditionally used to the genus. In addition to the diagnosis given previously, the new species can be differentiated from congeners surely identified at specific level, inhabiting rivers comprised in the NMAF, by a series of characters. The species differs from $A$. bahiensis (Steindachner), A. brevirhinus Eigenmann, A. brucutu, A. burgerai Zanata \& Camelier, A. epiagos, A. hamatilis, A. lorien, A. jacobinae Zanata \& Camelier, A. pelecus, A. rupestris, A. sincora, A. turmalinensis Triques, Vono \& Caiafa, and $A$. vermilion Zanata \& Camelier by having a conspicuous dark wide midlateral stripe extending from the rear of the clear area posterior to the humeral blotch to the end of middle caudal fin rays, not forming a conspicuous blotch on the caudal peduncle (vs. absence of conspicuous lateral stripe and/or presence of a conspicuous caudal blotch), from A. burgerai, A. epiagos, A. jacobinae, A. lorien, A. microschemos Bertaco \& Lucena, A. rupestris, $A$. sincora, and $A$. turmalinensis by having the highest body depth approximately at vertical through the dorsal-fin origin (vs. body deepest on a vertical approximately at midlength or posterior portion of pectoral fin), from A. brevirhinus by the presence of a vertically elongated conspicuous dark humeral blotch ( $v s$. presence of horizontally elongate black humeral blotch), and from A. pelecus by having 34-37 pored lateral line scales and humeral blotch with its ventral portion located ventrally to the lateral line series (vs. 38-39 pored lateral line scales and humeral blotch limited to the region above lateral line).

The endemic nature of the fish fauna of the rio de Contas is exemplified by eight endemic species, including Cyphocharax pinnilepis, Hasemania piatan, Hyphessobrycon brumado, Ituglanis agreste, Megaleporinus brinco, Nematocharax varii, Parotocinclus jimi Garavello, and the new species described herein. The rio de Contas basin ranks second in number of endemic fish species after the rio Paraguaçu basin, among river basins completely included in the Bahia State. Thus, the fish fauna of the rio de Contas, known up to date, is in agreement with the statement of previous authors about coastal drainages of eastern Brazil being recognized as a very distinct area in terms of their ichthyofauna, mainly expressed by the high endemism at species and genus level (e.g., Bizerril, 1994; Camelier, Zanata, 2014). Appart from endemicities restrict to the basin itself, according to Camelier, Zanata (2014), one of the few publications with somewhat broader taxonomic information on its fish fauna, 
high ichthyofaunistic similarities among the rio de Contas basin and a group of 16 coastal river basins from the NMAF is evident, more specifically with rios Cachoeira, Almada, Una, Pardo, and Jequitinhonha basins. Two species are shared exclusively by these five basins, forming the Central group of Camelier, Zanata (2014), Nematocharax venustus and Oligosarcus macrolepis (Steindachner). Astyanax varii is apparently endemic to the rio de Contas basin and, consequently, not present in other basins of the Central group.

Comparative material examined. Additional to Zanata, Camelier (2009) and Zanata et al. (2018): Astyanax lorien: MZUSP 123398, holotype, $66.4 \mathrm{~mm}$ SL; UFBA 8109, paratypes, 10, 38.1-56.1 mm SL, Brazil, Bahia, rio Paraguaçu basin. Astyanax rupestris: MZUSP 89567, holotype, $85.2 \mathrm{~mm}$ SL; UFBA 2789, paratypes, 19, 24.366.0 mm SL; Brazil, Bahia, rio Paraguaçu basin. Astyanax sincora: MZUSP 120747, holotype, $46.0 \mathrm{~mm} \mathrm{SL}$; UFBA 8200, paratypes, 49, 11.7-61.5 mm SL, Brazil, Bahia, rio Paraguaçu basin.

\section{Acknowledgments}

We thank André T. Silva (UESB) for the photo of the alive specimen. We also thank Victor Gomes (UFBA) for the identification of insects of the stomach contents. Funding for field work in which the new species also was collected was provided by CNPq (grant \# 476495/20105; \# 562335/2010-2). Authors were funded by CNPq (PC grant \# 423760/2018-1 and RB Protax \# 440534/2015-1), FAPESB (GV grant \# 310/2016), and FAPESP (PC grant \# 2016/19075-9; 2017/09321-5). Permission for collecting specimens was granted by IBAMA \# 13754-1.

\section{References}

Abell R, Thieme ML, Revenga C, Bryer M, Kottelat M, Bogutskaya N, Coad B, Mandrak N, Balderas SC, Bussing W, Stiassny MLJ, Skelton P, Allen GR, Unmack P, Naseka A, Ng R, Sindorf N, Robertson J, Armijo E, Higgins JV, Heibel TJ, Wikramanayake E, Olson D, López HL, Reis RE, Lundberg JG, Pérez MHS, Petry P. Freshwater ecoregions of the world: A new map of biogeographic units for freshwater biodiversity conservation. Bioscience. 2008; 58(5):403-14. https://doi. org/10.1641/B580507

Abilhoa V, Duboc LF. A new species of the freshwater fish genus Astyanax (Ostariophysi: Characidae) from the rio Iguaçu basin, southeastern Brazil. Zootaxa. 2007; 1587(1):43-52. http:// dx.doi.org/10.11646/zootaxa.1587.1.3

Affonso PRAM, Miranda VS, Medrado AS, Jacobina UP, Bitencourt JA, Almeida JS, Carneiro PLS. Chromosomes in focus: basic cytogenetics, light microscopy and the case of Neotropical fish. In: Méndez-Vilas A, Díaz J, editors. Modern research and educational topics in microscopy. Badajoz: Formatex; 2007. p.370-77.
Alcaraz HSV, Pavanelli CS, Bertaco VA. Astyanax jordanensis (Ostariophysi: Characidae), a new species from the rio Iguaçu basin, Paraná, Brazil. Neotrop Ichthyol. 2009; 7(2):185-90. http://dx.doi.org/10.1590/S1679-62252009000200008

Almirón AE, Azpelicueta MM, Casciotta JR. Astyanax ita sp. n. - a new species from the Río Iguazú basin, in Argentina (Teleostei, Characiformes, Characidae). Zool Abh. 2002; 52(1):3-10.

Azpelicueta MM, Almirón AE, Casciotta JR. Astyanax paris: A new species from the Río Uruguay basin of Argentina (Characiformes, Characidae). Copeia. 2002a; 2002(4):105256. https://doi.org/10.1643/0045-8511(2002)002[1052:APAN $\mathrm{SF}] 2.0 . \mathrm{CO} ; 2$

Azpelicueta MM, Casciotta JR, Almirón AE. Two new species of the genus Astyanax (Characiformes, Characidae) from the Paraná river basin in Argentina. Rev Suisse de Zool. 2002b; 109(2):243-60.

Azpelicueta MDM, Garcia JO. A new species of Astyanax (Characiformes, Characidae) from Uruguay river basin in Argentina, with remarks on hook presence in Characidae. Rev suisse de Zool. 2000; 107(2):245-58.

Azpelicueta MM, Loureiro M. Astyanax laticeps (Teleostei: Characiformes: Characidae) from rivers and streams of Uruguay. Vertebr Zool. 2009; 59(1):3-9.

Barreto SB, Silva AT, Batalha-Filho H, Affonso PRAM, Zanata AM. Integrative approach reveals a new species of Nematocharax (Teleostei: Characidae). J Fish Biol. 2018; 93(6):1151-62. https://doi.org/10.1111/jfb.13834

Bertaco VA. Astyanax douradilho, a new characid fish from the rio Tramandaí system, southern Brazil (Characiformes: Characidae). Zootaxa. 2014; 3794(3):492-500. http://dx.doi org/10.11646/zootaxa.3794.3.10

Bertaco VA, Carvalho FR, Jerep FC. Astyanax goyanensis (Miranda-Ribeiro, 1944), new combination and Astyanax courensis, new species (Ostariophysi: Characiformes): two Characidae from the upper rio Tocantins basin, Central Brazil. Neotrop Ichthyol. 2010; 8(2):265-75. http://dx.doi. org/10.1590/S1679-62252010000200004

Bertaco VA, Lucena CAS. Two new species of Astyanax (Ostariophysi: Characiformes: Characidae) from eastern Brazil, with a synopsis of the Astyanax scabripinnis species complex. Neotrop Ichthyol. 2006; 4(1):53-60. http://dx.doi. org/10.1590/S1679-62252006000100004

Bertaco VA, Lucena CAS. Redescription of Astyanax obscurus (Hensel, 1870) and A. laticeps (Cope, 1894) (Teleostei: Characidae): two valid freshwater species originally described from rivers of Southern Brazil. Neotrop Ichthyol. 2010; 8(1):720. http://dx.doi.org/10.1590/S1679-62252010000100002

Bertaco VA, Malabarba LR. Description of two new species of Astyanax (Teleostei: Characidae) from headwater streams of Southern Brazil, with comments on the " $A$. scabripinnis species complex". Ichthyol Explor Freshw. 2001; 12(3):221-34.

Bertaco VA, Vigo AC. A new species of Astyanax Baird \& Girard (Ostariophysi: Characidae) from the rio Taquari-Antas basin, southern Brazil. Neotrop Ichthyol. 2015; 13(2):265-72. http:// dx.doi.org/10.1590/1982-0224-20140145 
Birindelli JL, Britski HA, Garavello JC. Two new species of Leporinus Agassiz (Characiformes: Anostomidae) from eastern basins of Brazil, and redescription of L. melanopleura Günther. Neotrop Ichthyol. 2013; 11(1):9-23. http://dx.doi.org/10.1590/ S1679-62252013000100002

Bizerril CRSF. Análise taxonômica e biogeográfica da ictiofauna de água doce do leste brasileiro. Acta Biol Leopold. 1994; 16(1):51-80.

Burger R, Carvalho FR, Zanata AM. A new species of Astyanax Baird \& Girard (Characiformes: Characidae) from western Chapada Diamantina, Bahia, Brazil. Zootaxa. 2019; 4604(2):369-80. http://dx.doi.org/10.11646/zootaxa.4604.2.9

Camelier P, Zanata AM. Biogeography of freshwater fishes from the Northeastern Mata Atlantica freshwater ecoregion: distribution, endemism, and area relationships. Neotrop Ichthyol. 2014; 12(4):683-98. http://dx.doi.org/10.1590/1982-0224-20130228

Cetra M, Sarmento-Soares LM, Martins-Pinheiro RF. Peixes de riachos e novas Unidades de Conservação no sul da Bahia. Panam J Aquat Sci. 2010; 5(1):11-21.

Eigenmann $\mathrm{CH}$. New characins in the collection of the Carnegie Museum. Ann Carnegie Mus. 1911; 8(1): 164-181.

Eigenmann CH. The American Characidae. Mem Mus Comp Zool. 1921; 43(3):208-310.

Eigenmann CH. The American Characidae. Mem Mus Comp Zool. 1927; 43(4):311-428.

Fink WL, Weitzman SH. The so-called cheirodontin fishes of Central America with descriptions of two new species (Pisces: Characidae). Smith Contrib Zool. 1974; 172:1-45. http:// dx.doi.org/10.5479/si.00810282.172

Fricke R, Eschmeyer WN, editors. Guide to fish collections [Internet]. San Francisco: California Academy of Science; 2019. Available from: http://researcharchive.calacademy.org/ research/ichthyology/catalog/collections.asp

Fricke R, Eschmeyer WN, Van der Laan R, editors. Eschmeyer's catalog of fishes: genera, species, references [Internet]. San Francisco: California Academy of Science; 2019. Available from: http://researcharchive.calacademy.org/research/ichthyology/ catalog/fishcatmain.asp

Garavello JC, Sampaio FAA. Five new species of genus Astyanax Baird \& Girard, 1854 from rio Iguaçu, Paraná, Brazil (Ostariophysi, Characiformes, Characidae). Braz J Biol. 2010; 70(3):847-65. https://doi.org/10.1590/S151969842010000400016

Haluch CF, Abilhoa V. Astyanax totae, a new characid species (Teleostei: Characidae) from the upper rio Iguaçu basin, southeastern Brazil. Neotrop Ichthyol. 2005; 3(3):383-88. http://dx.doi.org/10.1590/S1679-62252005000300005

Ingenito LFS, Duboc LF. A new species of Astyanax (Ostariophysi: Characiformes: Characidae) from the upper rio Iguaçu basin, southern Brazil. Neotrop Ichthyol. 2014; 12(2):281-90. http:// dx.doi.org/10.1590/1982-0224-20130117

International Union for Conservation of Nature (IUCN). Standards and petitions subcommittee. Guidelines for using the IUCN Red List categories and criteria. Version 13 [Internet]. Gland; 2017. Available from: http://cmsdocs.s3.amazonaws.com/ RedListGuidelines.pdf
Lima SMQ, Neves CP, Campos-Paiva RM. Ituglanis agreste, a new catfish from the rio de Contas basin, northeastern Brazil (Siluriformes: Trichomycteridae). Neotrop Ichthyol. 2013; 11(3):513-24. http://dx.doi.org/10.1590/S167962252013000300005

Lucena CAS, Castro JB, Bertaco VA. Three new species of Astyanax from drainages of southern Brazil (Characiformes: Characidae). Neotrop Ichthyol. 2013; 11(3):537-52. http:// dx.doi.org/10.1590/S1679-62252013000300007

Lucena CAS, Zaluski AB, Lucena ZMS. Astyanax taurorum a new species from dos Touros River, Pelotas River drainage, an upland southern Brazilian river (Characiformes: Characidae). Zoologia. 2017; 34:e20174. http://dx.doi.org/10.3897/ zoologia.34.e20174

Mattos JLO, Wilson JEMC. Three new species of the 'Geophagus' brasiliensis species group from the northeast Brazil (Cichlidae, Geophagini). Zoosyst Evol. 2018; 94(2):325-37. https://doi.org/10.3897/zse.94.22685

Medrado AS, Figueiredo AVA, Waldschmidt AM, Mello Affonso PRA, Carneiro PLS. Cytogenetic and morphological diversity in populations of Astyanax fasciatus (Teleostei, Characidae) from Brazilian northeastern river basins. Genet Mol Biol. 2008; 31(1):208-14. http://dx.doi.org/10.1590/S141547572008000200007

Medrado AS, Mello Affonso PRA, Carneiro PLS, Vicari MR, Artoni RF, Costa MA. Allopatric divergence in Astyanax aff. fasciatus Cuvier, 1819 (Characidae, Incertae sedis) inferred from DNA mapping and chromosomes. Zool Anz. 2015; 257:119-29. https://doi.org/10.1016/j.jcz.2015.05.005

Melo FAG. A Serra dos Órgãos como barreira biogeográfica para peixes dos gêneros Astyanax Baird e Girard (1854) e Deuterodon Eigenmann (1907) (Teleostei: Characiformes: Characidae). [Master Dissertation]. Rio de Janeiro: Universidade Federal do Rio de Janeiro; 2000. Available from: https://pantheon.ufrj.br/bitstream/11422/3538/3/493384.pdf

Menezes NA, Weitzman SH. Two new species of Mimagoniates (Teleostei: Characidae: Glandulocaudinae), their phylogeny and biogeography and a key to the glandulocaudin fishes of Brazil and Paraguay. Proc Biol Soc Wash. 1990; 103(2):380-426.

Oliveira CAM, Abilhoa V, Pavanelli CS. Astyanax guaricana (Ostariophysi: Characidae), a new species from the rio Cubatão drainage, Paraná State, Southern Brazil. Neotrop Ichthyol. 2013; 11(2):291-96. http://dx.doi.org/10.1590/ S1679-62252013000200007

Oliveira CAM, Pavanelli CS, Bertaco VA. A new species of Astyanax Baird \& Girard (Characiformes: Characidae) from the upper rio Araguaia, Central Brazil. Zootaxa. 2017; 4320(1):173-82. http://dx.doi.org/10.11646/ zootaxa.4320.1.10

Pamponet VCC, Carneiro PLS, Mello Affonso PRA, Miranda VS, Silva Júnior JC, Oliveira CG, Gaiotto FA. A multi-approach analysis of the genetic diversity in populations of Astyanax aff. bimaculatus Linnaeus, 1758 (Teleostei: Characidae) from Northeastern Brazil. Neotrop Ichthyol. 2008; 6(4):621-30. http://dx.doi.org/10.1590/S1679-62252008000400010 
Rangel-Pereira FS. Gymnotus interruptus, a new species of electric fish from the rio de Contas basin, Bahia, Brazil (Teleostei: Gymnotiformes: Gymnotidae). Vertebr Zool. 2012; 62(3):36370. Available from: https://www.senckenberg.de/wp-content/ uploads/2019/08/03_vertebrate_zoology_62-3_rangelpereira_363-370.pdf

Sarmento-Soares LM, Britski HA, Anjos M, Zanata AM, MartinsPinheiro RF, Barretto MG. First record of genus Imparfinis from a northeastern coastal Brazilian river basin: I. borodini Mees \& Cala, 1989 in rio de Contas, Bahia. Check List. 2016; 12(1):1-7. https://doi.org/10.15560/12.1.1832

Silva AT. Composição e estrutura das assembleias de peixes de riachos da bacia do rio de Contas, Bahia, Brasil. [PhD Thesis]. Rio Claro: Universidade Estadual Paulista Júlio de Mesquita Filho; 2015. Available from: https://repositorio. unesp.br/bitstream/handle/11449/154654/000898322. pdf? sequence $=1 \&$ isAllowed $=\mathrm{y}$

Silva PC, Malabarba MC, Malabarba LR. Integrative taxonomy: Morphology and ancient DNA barcoding reveals the true identity of Astyanax taeniatus, a tetra collected by Charles Darwin during the Beagle's voyage. Zool Anz. 2019; 278:110 20. https://doi.org/10.1016/j.jcz.2018.12.007

Tagliacollo VA, Britzke R, Silva GSC, Benine RC. Astyanax pirapuan: a new characid species from the upper rio Paraguay system, Mato Grosso, Central Brazil (Characiformes, Characidae). Zootaxa. 2011; 2749:40-46. http://dx.doi. org/10.11646/zootaxa.2749.1.3

Taylor WR, Van Dyke GC. Revised procedures for staining and clearing small fishes and other vertebrates for bone and cartilage study. Cybium. 1985; 9:107-19.
Triques ML, Vono V, Caiafa EV. Astyanax turmalinensis, a new species from the rio Jequitinhonha basin, Minas Gerais, Brazil (Characiformes: Characidae: Tetragonopterinae). Aqua. 2003; 7(4):145-50.

Zanata AM, Camelier P. Hyphessobrycon brumado: a new characid fish (Ostariophysi: Characiformes) from the upper rio de Contas drainage, Chapada Diamantina, Bahia, Brazil. Neotrop Ichthyol. 2010; 8(4):771-77. http://dx.doi.org/10.1590/S167962252010000400006

Zanata AM, Burger R, Camelier P. Two new species of Astyanax Baird \& Girard (Characiformes: Characidae) from the upper rio Paraguaçu basin, Chapada Diamantina, Bahia, Brazil. Zootaxa. 2018; 4438:471-490. http://dx.doi.org/10.11646/ zootaxa.4438.3.3

Zanata AM, Lima FCT, Di Dario F, Gerhard P. A new remarkable and critically endangered species of Astyanax Baird \& Girard (Characiformes: Characidae) from Chapada Diamantina, Bahia, Brazil, with a discussion on durophagy in the Characiformes. Zootaxa. 2017; 4232:491-510. http://dx.doi.org/10.11646/ zootaxa.4232.4.2 